\title{
Relative Reactivity of Biogenic and Chemogenic Uraninite and Biogenic Noncrystalline U(IV)
}

\author{
José M. Cerrato, ${ }^{*} \ddagger$ Matthew N. Ashner, ${ }^{\ddagger}$ Daniel S. Alessi, ${ }^{\S}$ Juan S. Lezama-Pacheco, \\ Rizlan Bernier-Latmani, ${ }^{\S}$ John R. Bargar, " and Daniel E. Giammar \\ ${ }^{\ddagger}$ Department of Energy, Environmental, and Chemical Engineering, One Brookings Drive, Washington University, Saint Louis, \\ Missouri 63130, United States \\ ${ }^{\S}$ Environmental Microbiology Laboratory, École Polytechnique Fédérale de Lausanne, Lausanne, CH-1015, Switzerland \\ "Stanford Synchrotron Radiation Lightsource, SLAC, 2575 Sand Hill Road, Menlo Park, California 94025, United States
}

Supporting Information

ABSTRACT: Aqueous chemical extractions and X-ray absorption spectroscopy (XAS) analyses were conducted to investigate the reactivity of chemogenic uraninite, nanoparticulate biogenic uraninite, and biogenic monomeric $\mathrm{U}(\mathrm{IV})$ species. The analyses were conducted in systems containing a total $U$ concentration that ranged from 1.48 to 2.10 $\mathrm{mM}$. Less than $0.02 \%$ of the total $U$ was released to solution in extractions that targeted water-soluble and ion exchangeable fractions. Less than $5 \%$ of the total $U$ was solubilized via complexation with a 0.1 M solution of $\mathrm{NaF}$. Greater than $90 \%$ of the total U was extracted from biogenic uraninite and monomeric $\mathrm{U}(\mathrm{IV})$ after $6 \mathrm{~h}$ of reaction in an oxidizing solution of $50 \mathrm{mM} \mathrm{K} \mathrm{S}_{2} \mathrm{O}_{8}$. Additional oxidation experiments with lower concentrations $(2 \mathrm{mM}$ and $10 \mathrm{mM})$ of $\mathrm{K}_{2} \mathrm{~S}_{2} \mathrm{O}_{8}$ and $8.2 \mathrm{mg}$ $\mathrm{L}^{-1}$ dissolved oxygen suggested that monomeric $\mathrm{U}(\mathrm{IV})$ species are more

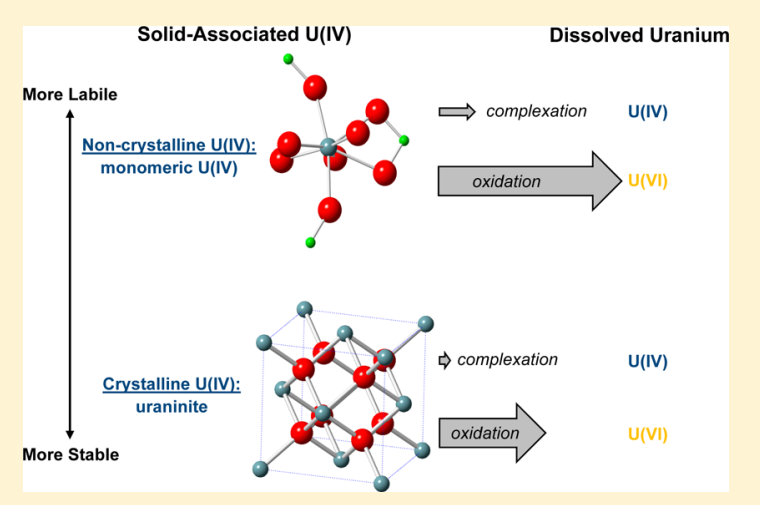
labile than biogenic uraninite; chemogenic uraninite was much less susceptible to oxidation than either form of biogenic U(IV). These results suggest that noncrystalline forms of U(IV) may be more labile than uraninite in subsurface environments. This work helps fill critical gaps in our understanding of the behavior of solid-associated U(IV) species in bioremediated sites and natural uranium ore deposits.

\section{INTRODUCTION}

The chemical stability of U(IV) is of central importance to the effectiveness of bioremediation techniques to mitigate subsurface uranium (U) contamination and to the management of in situ leach uranium mining. ${ }^{1,2}$ Knowledge of the molecular-scale speciation and reactivity of reduced $\mathrm{U}(\mathrm{IV})$ in subsurface environments is crucial to optimizing the long-term performance of in situ bioremediation strategies. The application of in situ uranium bioremediation, which stimulates the growth of microbes and results in the direct and indirect enzymatic reduction of soluble $\mathrm{U}(\mathrm{VI})$ to less soluble $\mathrm{U}(\mathrm{IV})$ species, was proposed in 1992, 3,4 and has been tested at the field scale over the past decades. ${ }^{5-7}$ However, the relative stability of U(IV) products in uranium-contaminated field sites remains poorly understood.

Although uraninite was long assumed to be the sole product of in situ bioremediation, ${ }^{6,8}$ recent studies have shown that other poorly ordered or noncrystalline U(IV) products can form. $^{2,8-12}$ These include U(IV) bound to biomass or precipitated as poorly ordered solids [most likely bound to carboxylate, carbonate, or phosphate ligands $\left.{ }^{9-11,13}\right]$. Monomeric $\mathrm{U}(\mathrm{IV})$ is a dominant product of $\mathrm{U}(\mathrm{VI})$ bioreduction in shallow aquifer sediments ${ }^{2}$ and also has been observed in flow- through column experiments with aquifer sediments performed to evaluate uranium immobilization and speciation following biostimulation. ${ }^{14}$ Monomeric U(IV) can be formed as a product of $\mathrm{U}(\mathrm{VI})$ reduction in the presence of $\mathrm{Fe}(\mathrm{II})$ in solids, biogenic vivianite, magnetite presorbed with phosphate, and by direct microbial reduction of $\mathrm{U}(\mathrm{VI}) ;^{11,14-16}$ the presence of phosphate hinders uraninite formation and instead causes the formation of monomeric U(IV) when U(VI) is reduced by phosphate-reacted biogenic magnetite and by bacteria. ${ }^{11,15}$ Because uranium is not bound directly to other $U$ atoms via shared atoms in these species, they have been referred to as "monomeric" or "mononuclear" U(IV). ${ }^{12}$ However, in many $\mathrm{U}(\mathrm{IV})$-phosphates, the ligand probably occurs as a polymeric network, a motif likely to appear in bioreduced samples. Such complexes have been referred to as "coordination polymers". To account for the range of U(IV) coordination possibilities, we will use the term "monomeric U(IV)" here to include U(IV)

Received: April 16, 2013

Revised: July 25, 2013

Accepted: August 1, 2013

Published: August 1, 2013 
atoms coordinated to polymeric networks and in truly monomeric complexes.

Several geochemical factors impact the stability of U(IV) in subsurface environments. For instance, uraninite dissolution rates increase with increasing dissolved oxygen and decreasing $\mathrm{pH} .{ }^{17-19}$ The presence of carbonate promotes the dissolution of uraninite at circumneutral $\mathrm{pH}$ by facilitating the detachment of surface-associated $U$ under oxidizing and reducing conditions, ${ }^{20}$ and carbonate can also solubilize monomeric $\mathrm{U}(\mathrm{IV})$ species from solids. ${ }^{10}$ Groundwater cations such as $\mathrm{Ca}^{2+}$, $\mathrm{Zn}^{2+}$, and $\mathrm{SiO}_{4}{ }^{4-}$ have been shown to inhibit uraninite dissolution. ${ }^{21,22}$ Thus, a wide range of aqueous chemistry conditions should be considered when evaluating the reactivity of U(IV) species in subsurface environments. The lability of solid U(IV) species due to reaction with complexants and oxidants can result in soluble $U$ products that could be more susceptible to mobilization by advective and diffusive transport processes in the environment.

Little is known about the relative reactivity of nonuraninite products of biological U(VI) reduction. Recent experiments showed that monomeric $\mathrm{U}(\mathrm{IV})$ produced by biomass, biogenic vivianite, or phosphate-reacted magnetite, or in a field sediment from Rifle, $\mathrm{CO}$, were more labile than uraninite when exposed to an anoxic $1 \mathrm{M} \mathrm{NaHCO}_{3}$ solution at $\mathrm{pH} 8.7 .{ }^{12}$ However, the lability of monomeric U(IV) species at field-relevant bicarbonate concentrations has not been tested. Although anecdotal evidence suggests that monomeric $\mathrm{U}(\mathrm{IV})$ is more labile than uraninite under oxidizing conditions, limited experimental data exist to support this assumption. It is important to understand the differences in lability among U(IV) species under oxidizing conditions, as knowledge of their reoxidation potential directly bears on the feasibility of using in situ bioremediation to immobilize uranium contamination. ${ }^{23,24}$ Understanding the differences in reactivity between U(IV) species is also relevant to understand ore genesis and uranium mobility in reduced sediments of contaminated aquifers. ${ }^{2}$

Chemical extractions can be used to assess the reactivity of different $\mathrm{U}(\mathrm{IV})$ and $\mathrm{U}(\mathrm{VI})$ species. Data obtained from chemical extractions are usually complementary to spectroscopic data and can also be used to help interpret spectroscopic results. For example, bicarbonate extractions have been used to quantitatively distinguish monomeric U(IV) from uraninite; monomeric U(IV) can be extracted from biogenic uraninite after reaction with an anoxic $1 \mathrm{M} \mathrm{NaHCO}_{3}$ solution at $\mathrm{pH}$ 8.7. ${ }^{12}$ Additionally, applying lower concentrations of sodium bicarbonate $\left(\sim 50-100 \mathrm{mM} \mathrm{NaHCO}_{3}\right)$ at $\mathrm{pH} 8.3$ can serve as a pretreatment step to remove traces of $\mathrm{U}(\mathrm{VI}) .{ }^{12}$ A recent study developed a sequential extraction method for determining iron and uranium redox speciation in reactions of $\mathrm{U}(\mathrm{VI})$ with $\mathrm{Fe}$ (II)-bearing clays; the method involved the extraction of all $\mathrm{U}$ from the solid in strong acid followed by a $\mathrm{U}(\mathrm{VI})$-specific analytical method. ${ }^{25}$

The objective of this study was to evaluate the release of $U$ from uraninite (chemogenic and biogenic) and biomassassociated monomeric U(IV) species under aqueous chemical conditions targeting U(IV) fractions that are water-soluble, ion exchangeable, amenable to complexation by a ligand, and oxidizable. Uranium $\mathrm{L}_{\mathrm{III}}$-edge X-ray absorption spectroscopy (XAS) was employed to characterize differences in the local molecular structure of $U$ between unreacted control samples and those exposed to the various chemical extractions. The results obtained from this investigation, performed under controlled laboratory conditions, serve as a foundation toward understanding the reactivity of these U(IV) species in natural and bioremediated sediments.

\section{MATERIALS AND METHODS}

Materials. All reagents used in this study were certified analytical grade or better and used without further purification. Chemogenic uraninite was synthesized using the protocol outlined in Ulrich et al. ${ }^{19}$ Briefly, studtite was precipitated by reaction of uranyl nitrate with hydrogen peroxide, dialyzed against ultrapure water, dried, and reduced to uraninite by heating to $400{ }^{\circ} \mathrm{C}$ with $\mathrm{H}_{2}(\mathrm{~g})$. X-ray diffraction analysis and scanning electron microscopy measurements confirmed that this synthesis yielded crystalline $\mathrm{UO}_{2}$ particles with mean diameters of about $100-200 \mathrm{~nm} .{ }^{19}$ Uraninite preparation and anoxic experiments presented in this study were conducted in an anaerobic chamber (Coy Laboratory Products Inc., Grass Lake, Michigan) containing a gas mixture of 95\% (volume/ volume, v/v) $\mathrm{N}_{2}(\mathrm{~g})$ and $5 \%(\mathrm{v} / \mathrm{v}) \mathrm{H}_{2}(\mathrm{~g})$ circulated through a $\mathrm{Pd}$ catalyst and silica gel.

Biomass-associated uraninite and monomeric U(IV) species were produced via microbial $\mathrm{U}(\mathrm{VI})$ reduction according to the methods outlined in Bernier-Latmani et al. ${ }^{10}$ Briefly, Shewanella oneidenis MR-1 was cultured and grown in Luria-Bertani (LB) medium as described in a previous study ${ }^{26}$ and then harvested by centrifugation at $8000 \mathrm{~g}$ for $10 \mathrm{~min}$ during the late exponential growth phase. Cells were washed in an anoxic solution containing $30 \mathrm{mM} \mathrm{NaHCO}_{3}$ and $20 \mathrm{mM}$ PIPES buffer set to $\mathrm{pH} 6.8$ (BP medium) to remove any remaining growth medium. Following the washing step, cells were resuspended to an optical density $\left(\mathrm{OD}_{600}\right)$ of 1.0 in an anaerobic chamber $\left(97 \% \mathrm{~N}_{2} / 3 \% \mathrm{H}_{2}\right)$ in either BP medium to favor the production of uraninite or in Widdel Low Phosphate (WLP) medium (Supporting Information [SI], Table S1) to favor the production of monomeric $\mathrm{U}(\mathrm{IV})$. Biogenic uraninite particles had mean diameters of approximately $3.5 \mathrm{~nm}$ as noted in previous studies. ${ }^{8,19}$ To initiate uranium reduction, media were amended with $20 \mathrm{mM} \mathrm{L}(+)$-lactic acid and $1 \mathrm{mM}$ uranyl acetate. Following reduction, cell suspensions were collected by centrifugation, resuspended in a small volume of anoxic water, placed in serum bottles with a $3 \% \mathrm{H}_{2} / 97 \% \mathrm{~N}_{2}$ headspace, sealed within Mylar bags purged with $\mathrm{N}_{2}$, and shipped from EPFL to Washington University using an overnight delivery service. The final concentration of uranium in the cell slurries was approximately $6780 \mathrm{mg} \mathrm{L}^{-1}$. Alessi et al. ${ }^{12}$ found that the system favoring uraninite production (BP medium) produces a mixture of approximately $65 \%$ biogenic uraninite and $35 \%$ monomeric U(IV), whereas the monomeric U(IV) favoring system (WLP medium) produces approximately 90\% monomeric U(IV) and $10 \%$ biogenic uraninite. These contents of monomeric U(IV) and biogenic uraninite for the materials used in this study were verified by the bicarbonate extraction method proposed by Alessi et al.; ${ }^{12}$ experiments were performed both at EPFL and Washington University, obtaining reproducible results.

Procedure for Chemical Extractions. Before beginning extraction experiments, each U(IV) material had its initial total $\mathrm{U}$ content precisely determined by analysis following digestion. For the acid digestion, $20 \mathrm{mg}$ of chemogenic uraninite, or 1.095 $\mathrm{mL}$ of monomeric $\mathrm{U}(\mathrm{IV})$ or biogenic uraninite slurries were loaded into $50 \mathrm{~mL}$ digestion tubes. The tubes were then filled with $8 \mathrm{~mL}$ of concentrated $\mathrm{HNO}_{3}(67-70 \%$ by mass), $2 \mathrm{~mL}$ concentrated $\mathrm{HCl}$ (34-37\% by mass), and $40 \mathrm{~mL}$ of deionized water, and placed in a heated digestion block held at $100{ }^{\circ} \mathrm{C}$ for 
Table 1. Summary of the Samples and Chemical Extractants Used in This Study

\begin{tabular}{|c|c|c|}
\hline sample name & sample description & chemical extractant(s) \\
\hline Mono U(IV) & $90 \%$ monomeric $\mathrm{U}(\mathrm{IV})$ and $10 \%$ biogenic uraninite & $\begin{array}{l}\text { deionized water, } \mathrm{NH}_{4} \mathrm{NO}_{3}, \mathrm{NaF}, \mathrm{K}_{2} \mathrm{~S}_{2} \mathrm{O}_{8} \text {, } \\
\text { and DO }\end{array}$ \\
\hline Bio $\mathrm{UO}_{2}$ & $\begin{array}{l}\text { biogenic uraninite not washed with } \mathrm{HCO}_{3}{ }^{-} \text {, }[\text { which contains } 65 \% \text { biogenic uraninite and } \sim 35 \% \\
\text { monomeric } \mathrm{U}(\mathrm{IV})]\end{array}$ & $\begin{array}{l}\text { deionized water, } \mathrm{NH}_{4} \mathrm{NO}_{3}, \mathrm{NaF}, \mathrm{K}_{2} \mathrm{~S}_{2} \mathrm{O}_{8} \text {, } \\
\text { and DO }\end{array}$ \\
\hline Chem $\mathrm{UO}_{2}$ & $100 \%$ chemogenic uraninite & $\begin{array}{l}\text { deionized water, } \mathrm{NH}_{4} \mathrm{NO}_{3}, \mathrm{NaF}, \mathrm{K}_{2} \mathrm{~S}_{2} \mathrm{O}_{8} \text {, } \\
\text { and DO }\end{array}$ \\
\hline $\begin{array}{l}\text { Mono-Chem Mix } \\
\text { Anoxic }\end{array}$ & $50 \%$ monomeric $\mathrm{U}(\mathrm{IV})+50 \%$ chemogenic uraninite (anoxic control) & $\mathrm{HCO}_{3}^{-}$ \\
\hline $\begin{array}{l}\text { Mono-Chem Mix } \\
\text { Oxidized }\end{array}$ & $50 \%$ monomeric $\mathrm{U}(\mathrm{IV})+50 \%$ chemogenic uraninite & $\mathrm{K}_{2} \mathrm{~S}_{2} \mathrm{O}_{8}$ \\
\hline washed $\mathrm{Bio} \mathrm{UO}_{2}$ & biogenic uraninite washed with $1 \mathrm{M} \mathrm{HCO}_{3}^{-}$[to remove monomeric U(IV)] & $\mathrm{DO}$ \\
\hline
\end{tabular}

$4 \mathrm{~h}$ to achieve complete digestion. An aliquot of the resulting digest was then filtered through a $0.22 \mu \mathrm{m}$ pore-size filter membrane (PTFE, Millipore) and diluted as necessary for ICPMS analysis. This filtration step was effective for removing uraninite particles; stable colloids were not noticed. Each digestion was performed in duplicate. The stock slurries of biogenic uraninite and monomeric U(IV) were found to have total $U$ concentrations of $28.5 \mathrm{mM}$. Prior to reaction with any specific extractant, chemogenic uraninite samples were reacted with $50 \mathrm{mM} \mathrm{NaHCO}$ at $\mathrm{pH} 8.3$ for $1 \mathrm{~h}$ to remove traces of $\mathrm{U}(\mathrm{VI})$ present in the sample. This step was shown by Alessi et al. ${ }^{12}$ to selectively mobilize U(VI). The samples were then washed in anoxic deionized water buffered with $0.01 \mathrm{M} 3-(\mathrm{N}$ morpholino)propanesulfonic acid (MOPS) at $\mathrm{pH} 7$ for $1 \mathrm{~h}$ to remove excess bicarbonate and U(VI).

Chemical extractions were conducted to evaluate the relative reactivity of chemogenic and biogenic uraninite, and monomeric U(IV). For each extraction, $20 \mathrm{mg}$ of chemogenic uraninite, or $1.095 \mathrm{~mL}$ of monomeric U(IV) or biogenic uraninite slurries, respectively, were reacted in $20 \mathrm{~mL}$ (for biogenic U(IV) samples) or $50 \mathrm{~mL}$ (for chemogenic uraninite) of solution to achieve a target $U$ loading ranging from 0.35 $0.5 \mathrm{~g} \mathrm{~L}^{-1}(1.48-2.10 \mathrm{mM} \mathrm{U})$. Water-soluble extractions were performed for $24 \mathrm{~h}$ using deionized water at $\mathrm{pH} 7$ buffered with $0.01 \mathrm{M}$ MOPS. Ion exchangeable extractions were conducted for $24 \mathrm{~h}$ using a $1 \mathrm{M} \mathrm{NH}_{4} \mathrm{NO}_{3}$ solution set to $\mathrm{pH} 7$ and buffered with 0.01 M MOPS. Ligand extractable experiments were performed for $24 \mathrm{~h}$ using $0.1 \mathrm{M} \mathrm{NaF}$ buffered to $\mathrm{pH} 6$ with $0.01 \mathrm{M}$ 2-(N-morpholino)ethanesulfonic acid (MES). Fluoride was chosen as the complexant based on chemical equilibrium modeling (illustrated in Figure S1 of the SI) that indicated that it had a stronger affinity for $\mathrm{U}(\mathrm{IV})$ at $\mathrm{pH} 6$ than would $1 \mathrm{M}$ bicarbonate at $\mathrm{pH} 8.7 ; 0.1 \mathrm{M} \mathrm{F}^{-}$is calculated to fully dissolve a $1.48 \mathrm{mM}$ loading of uraninite at $\mathrm{pH} 6.0$ whereas $1 \mathrm{M}$ bicarbonate could not fully dissolve the uraninite at any $\mathrm{pH}$, which was also confirmed by the experimental studies of Alessi et al. ${ }^{10}$ Oxidizable fractions of $\mathrm{U}$ were determined using a solution of $50 \mathrm{mM}$ potassium persulfate $\left(\mathrm{K}_{2} \mathrm{~S}_{2} \mathrm{O}_{8}\right)$ and $100 \mathrm{mM}$ $\mathrm{NaHCO}_{3}$ (6 $\mathrm{h}$ of reaction time). Persulfate was selected because of its oxidizing strength, and $100 \mathrm{mM} \mathrm{NaHCO}$ was included to mobilize the $\mathrm{U}(\mathrm{VI})$ produced by oxidation. Additional experiments with dissolved oxygen (DO), a milder oxidant than persulfate and a reactant of major environmental relevance, as well as at lower concentrations of persulfate were also conducted (see next subsection). Samples were filtered through $0.22 \mu \mathrm{m}$ pore-size filter membranes (PTFE, Millipore). After extractions, selected solid samples were preserved in the anaerobic chamber prior to XAS analyses for further characterization.
Additional Oxidation Experiments. The effects of $\mathrm{K}_{2} \mathrm{~S}_{2} \mathrm{O}_{8}$ and $\mathrm{DO}$ on the oxidation of chemogenic uraninite, biogenic uraninite, and monomeric U(IV) were studied as a function of time and oxidant concentration. Persulfate extraction solutions consisted of $100 \mathrm{mM} \mathrm{NaHCO}$ and $\mathrm{K}_{2} \mathrm{~S}_{2} \mathrm{O}_{8}$ added at concentrations of 2,10 , and $50 \mathrm{mM}$. Experiments with dissolved oxygen were conducted using 100 $\mathrm{mM} \mathrm{NaHCO}{ }_{3}$ and $8.2 \mathrm{mg} \mathrm{L}^{-1} \mathrm{DO}\left(0.26 \mathrm{mM} \mathrm{O}_{2}\right)$, which corresponds to the concentration in equilibrium with air at 25 ${ }^{\circ} \mathrm{C}$. Mixtures of chemogenic uraninite, biogenic uraninite, and monomeric U(IV) were prepared to evaluate the selectivity of persulfate and oxygen to extract specific U(IV) species. Mixtures consisting of $50 \%$ monomeric U(IV) and $50 \%$ chemogenic uraninite by mass were prepared in a fixed volume of $50 \mathrm{~mL}$ (target $\mathrm{U}$ loading of $0.5 \mathrm{~g} \mathrm{~L}^{-1}$ ) of anoxic deionized water inside an anaerobic chamber. As previously stated, the biogenic uraninite consists of approximately $65 \%$ uraninite and $35 \%$ monomeric U(IV) associated to biomass. ${ }^{12}$ As such, two sets of biogenic uraninite samples were prepared for selected experiments. In one set, the monomeric U(IV) fraction was removed from these samples with a $1 \mathrm{M} \mathrm{NaHCO}_{3}$ solution as previously described ${ }^{10}$ prior to the oxidation experiments so that only the biogenic uraninite fraction remained. The other set was extracted without removing the monomeric U(IV). The samples and chemical extractants used in this study are summarized in Table 1. Selected solid samples from these experiments were saved for XAS analyses for further characterization.

Solution Chemistry Analyses. Total dissolved U was measured by inductively coupled plasma mass spectrometry (ICP-MS, Agilent 7500ce). Aqueous samples were diluted in a solution of $2 \% \mathrm{HNO}_{3}$. The $\mathrm{U}$ detection limit was less than 0.01 $\mu \mathrm{g} \mathrm{L}^{-1}$ for a $95 \%$ confidence level based on comparing the statistical difference between the standard deviations obtained from measuring the blank and a $0.05 \mu \mathrm{g} \mathrm{L}^{-1} \mathrm{U}$ standard seven times. ${ }^{27}$ The $\mathrm{pH}$ measurements were taken using a $\mathrm{pH}$ electrode (Accumet) and meter (Accumet $\mathrm{AB} 15 \mathrm{pH}$ meter).

X-ray Absorption Spectroscopy. XAS measurements were performed at the Stanford Synchrotron Radiation Lightsource (SSRL). Uranium $\mathrm{L}_{\mathrm{III}}$-edge spectra were obtained at beamline 4-1 using a $\mathrm{Si}(220)$ monochromator calibrated using Y foil (Y K edge energy $17038.4 \mathrm{eV}$ ). Prior to XAS analyses, samples were stored and loaded into holders in an anaerobic chamber (described above) prior to and after being shipped to SSRL in a hermetically sealed stainless steel shipping can (Schuett-biotec GmbH, Göttingen, Germany). Samples were either dried and homogenized with boron nitride or filtered from suspensions onto $0.2 \mu \mathrm{m}$ nitrocellulose membranes; samples were mounted in aluminum holders covered 
with Kapton tape. The spectra were measured in fluorescence and transmission mode using a 13-element germanium detector or a Lytle-type ionization chamber and $\mathrm{N}_{2}$-filled ionization chambers, respectively. For each sample the results of 2-6 scans were averaged. Postbackground subtraction and data normalization to the subtracted EXAFS were performed by standard methods using IFFEFIT and the Horae program suite. $^{28}$ Data were Fourier transformed for the $k$ range of 3$10.2 \AA^{-1}$ using a Kaiser-Bessel window with a $d k=3$; the upper limit of the Fourier transform range was chosen to avoid multielectron excitations observed at $k \approx 10.5 \AA^{-1}$ in monomeric $\mathrm{U}(\mathrm{IV}) .^{29}$

Chemical Equilibrium and Kinetic Modeling. MINEQL $+\mathrm{v} 4.6^{30}$ was used to calculate equilibrium solubility. The default database was updated to include the equilibrium constants and reactions included in the latest critically revised thermodynamic databases; ${ }^{31,32}$ the full set of reactions is presented in Table S2 SI.

The rates of U(IV) oxidation were analyzed by interpreting the rate of soluble $\mathrm{U}(\mathrm{VI})$ production as a first-order process with respect to the amount of U(IV) species present (eq 1). Given the constraint that the total uranium in the system was constant (eq 2), this first-order rate model yields an expression for the concentration of soluble $\mathrm{U}(\mathrm{VI})\left(\mathrm{mol} \mathrm{L}^{-1}\right)$ as a function of time (eq 3),

$$
\begin{aligned}
& \frac{\mathrm{d}[\mathrm{U}(\mathrm{VI})]}{\mathrm{d} t}=k[\mathrm{U}(\mathrm{VI})] \\
& {[\mathrm{U}(\mathrm{IV})]+[\mathrm{U}(\mathrm{VI})]=\text { constant }=[\mathrm{U}(\mathrm{IV})]_{0}} \\
& {[\mathrm{U}(\mathrm{VI})]=[\mathrm{U}(\mathrm{IV})]_{0}\left(1-\mathrm{e}^{-k t}\right)}
\end{aligned}
$$

where $[\mathrm{U}(\mathrm{IV})]_{0}$ is the initial concentration of $\mathrm{U}(\mathrm{IV})$ species $\left.(\mathrm{mol} \mathrm{L})^{-1}\right)$ and $k$ is the first-order rate constant $\left(\mathrm{s}^{-1}\right.$ or mol $\left.\mathrm{U}(\mathrm{VI}) \cdot \mathrm{mol}(\mathrm{IV})^{-1} \cdot \mathrm{s}^{-1}\right)$. Rate constants can then be converted to forms that express the $\mathrm{U}(\mathrm{VI})$ production relative to the mass of $\mathrm{U}(\mathrm{IV})$ species $\left(\mathrm{mol} \mathrm{U}(\mathrm{VI}) \cdot \mathrm{g} \mathrm{U}(\mathrm{IV})^{-1} \cdot \mathrm{s}^{-1}\right)$. In these units, which are useful for comparison with previously reported uraninite dissolution rates, the rate constant is also equal to the initial dissolution rate $\left(\mathrm{R}_{\text {init }}\right)$ by rearrangement of eq 1 .

$$
k=R_{\text {init }}=\frac{\left(\frac{\mathrm{d}[\mathrm{U}(\mathrm{VI})]}{\mathrm{d} t}\right)_{\text {init }}}{[\mathrm{U}(\mathrm{IV})]_{0}}
$$

Because the samples of monomeric U(IV) and biogenic uraninite were not completely pure, the release of $\mathrm{U}(\mathrm{VI})$ for these systems was interpreted as the sum of the release from each form of U(IV) (eq 5).

$$
\begin{aligned}
{[\mathrm{U}(\mathrm{VI})]=} & {[\mathrm{U}(\mathrm{IV})]_{\text {mono }, 0}\left(1-\mathrm{e}^{-k_{\text {mono }} t}\right)+[\mathrm{U}(\mathrm{IV})]_{\mathrm{bio}-\mathrm{UO}_{2}, 0} } \\
& \left(1-\mathrm{e}^{-k_{\text {bio-Uo }_{2}}{ }^{t}}\right)
\end{aligned}
$$

The data sets for the biogenic uraninite and monomeric U(IV) extractions in water in equilibrium with atmospheric oxygen were used simultaneously to find the optimal rate constants to fit the experimental data. Additional details of the optimization procedure are presented in the Supporting Information. For chemogenic uraninite, the extent of dissolution was so low that the concentration of $\mathrm{U}(\mathrm{IV})$ was essentially constant over the duration of the experiment and the rate constant could be determined by linear regression of the $\mathrm{U}(\mathrm{VI})$ concentration versus time.

\section{RESULTS AND DISCUSSION}

Experiments Targeting U Fractions That Are Water Soluble, Ion Exchangeable, Amenable to Complexation, or Oxidizable. Negligible fractions of total U, i.e., less than $0.02 \%$, were extracted during the reaction of deionized water (water-soluble) and $\mathrm{NH}_{4} \mathrm{NO}_{3}$ (ion exchangeable) with the three U(IV) species included in this study (Figure 1). Higher U

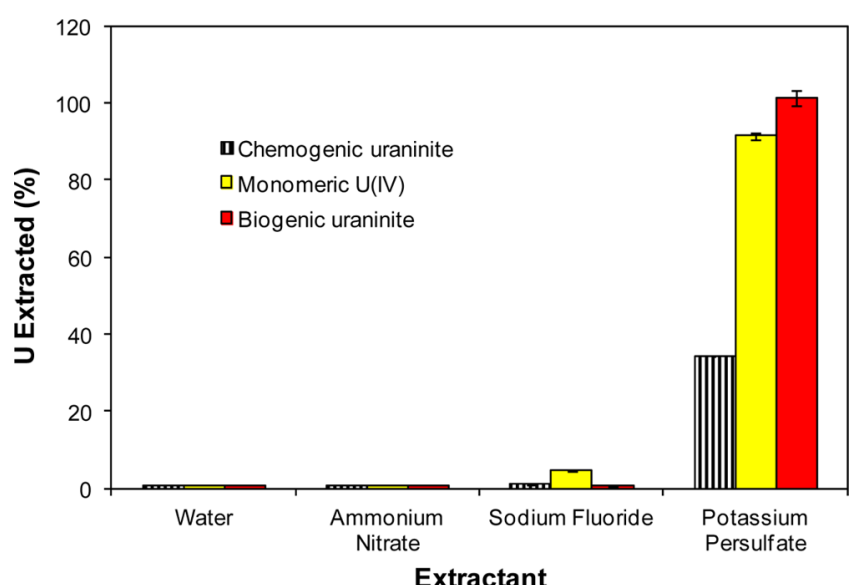

Figure 1. U extracted (\%) from water-soluble, ion exchangeable, ligand extractable, and oxidizable extraction experiments with chemogenic uraninite, monomeric $\mathrm{U}(\mathrm{IV})$, and biogenic uraninite (not washed with $\mathrm{HCO}_{3}{ }^{-}$). The total $\mathrm{U}$ concentration for these experiments ranged from 1.48 to $2.10 \mathrm{mM}$. Less than $0.02 \%$ of the total amounts were extracted from the reaction with deionized water (water-soluble) and $\mathrm{NH}_{4} \mathrm{NO}_{3}$ (ion exchangeable). Potassium persulfate extractions presented in this figure were conducted with $50 \mathrm{mM} \mathrm{K}_{2} \mathrm{~S}_{2} \mathrm{O}_{8}$ and $6 \mathrm{~h}$ of reaction.

release was obtained from monomeric $\mathrm{U}(\mathrm{IV})$ as compared to biogenic and chemogenic uraninite for the $\mathrm{NaF}$ extractions that mobilized U(IV) by complexation. This result is consistent with the study of Alessi et al., ${ }^{12}$ which reported that monomeric $\mathrm{U}(\mathrm{IV})$ is more labile than biogenic uraninite when reacted with $1 \mathrm{M}$ bicarbonate. However, the reaction with $0.1 \mathrm{M} \mathrm{NaF}$ still resulted in extraction of only $5 \%$ of the $U$ from biomassassociated monomeric U(IV) species, $0.3 \%$ of the $U$ in biogenic uraninite, and $1 \%$ of the $U$ in chemogenic uraninite. The equilibrium calculations shown in Figure $\mathrm{S} 1$ in SI indicate that all of the uraninite $(1.48 \mathrm{mM})$ would dissolve if the system were allowed to reach equilibrium with $0.1 \mathrm{M} \mathrm{NaF}$, suggesting that the release of U(IV) to solution is controlled by kinetics and that a reaction time longer than $24 \mathrm{~h}$ would be necessary to observe higher U release.

The highest fractions of $U$ released were observed from oxidation experiments with $50 \mathrm{mM} \mathrm{K} \mathrm{S}_{2} \mathrm{O}_{8}$ after $6 \mathrm{~h}$ of reaction time. These extractions mobilized $35 \%$ of total $U$ in chemogenic uraninite and $90 \%$ and $100 \%$ of total $U$ in monomeric U(IV) and biogenic uraninite, respectively. Additional experiments were pursued to further investigate the reactivity of monomeric $\mathrm{U}(\mathrm{IV})$, biogenic uraninite, and chemogenic uraninite under oxidizing conditions.

Oxidation Experiments with Potassium Persulfate and Dissolved Oxygen. Because $50 \mathrm{mM} \mathrm{K} \mathrm{K}_{2} \mathrm{O}_{8}$ could oxidize more than $90 \%$ of the biogenic $\mathrm{U}(\mathrm{IV})$ species after $6 \mathrm{~h}$ of reaction, further investigation of the susceptibility of U(IV) species to oxidative mobilization focused on the rates of release and examined a wider range of conditions. Experiments using 
$50 \mathrm{mM} \mathrm{K} \mathrm{K}_{2} \mathrm{O}_{8}$ and sampled at hourly intervals showed that $\sim 97 \%$ of the biogenic uraninite was oxidized within the first hour (SI, Figure S2). Thus, the kinetics of oxidation of U(IV) species were studied by obtaining solution samples at hourly intervals and at lower concentrations of potassium persulfate $(2$ $\mathrm{mM}$ and $10 \mathrm{mM} \mathrm{K}_{2} \mathrm{~S}_{2} \mathrm{O}_{8}$ ). It is worth noting that $\mathrm{K}_{2} \mathrm{~S}_{2} \mathrm{O}_{8}$ was in excess of $\mathrm{U}(\mathrm{IV})$ [added as $1.48 \mathrm{mM} \mathrm{U}$ ], even at concentrations of $2 \mathrm{mM}$ and $10 \mathrm{mM}$, based on the $1: 1$ stoichiometry of the redox reaction between $\mathrm{U}(\mathrm{IV})$ and persulfate:

$$
\mathrm{U}(\mathrm{IV})+\mathrm{S}_{2} \mathrm{O}_{8}{ }^{2-} \rightarrow \mathrm{U}(\mathrm{VI})+2 \mathrm{SO}_{4}{ }^{2-}
$$

We also evaluated the effect of dissolved oxygen (DO), which is a milder oxidant and a reactant of major environmental relevance, in the oxidation of the three forms of $\mathrm{U}(\mathrm{IV})$.

Chemogenic uraninite was more resistant to oxidation than either form of biogenic U(IV) (Figure 2 and Table 2). The differences in $U$ released between the different $U(I V)$ species are particularly noticeable during the first $3 \mathrm{~h}$ of these oxidation experiments. Previous studies have provided a detailed characterization of the structure and nanoparticulate nature of biogenic uraninite. ${ }^{8,33}$ It is likely that nanoparticles of biogenic uraninite (mean particle diameter $\sim 3.5 \mathrm{~nm}$ ) are more reactive than chemogenic uraninite particles (mean particle diameter $\sim 100-200 \mathrm{~nm}$ ) due to the difference in size and reactive surface area. The specific surface area of chemogenic uraninite using this synthesis method was previously measured as $5.9 \mathrm{~m}^{2} /$ $\mathrm{g}$ and that of a biogenic uraninite washed with $\mathrm{NaOH}$ was 50.1 $\mathrm{m}^{2} / \mathrm{g}$ from BET-N $\mathrm{N}_{2}$ measurement; ${ }^{20}$ the surface area of the biogenic uraninite is lower than would be predicted for welldispersed uraninite nanoparticles, and precise quantification of reactive surface area is not possible. ${ }^{19}$ Another investigation reported higher mass-normalized dissolution rates for biogenic uraninite than chemogenic uraninite under moderately oxidizing conditions in the presence of $1 \mathrm{mM}$ dissolved inorganic carbon at a $\mathrm{pH}$ range of $7.6-8.2 .^{20}$ This is consistent with the higher fraction of $U$ oxidized in the presence of $\mathrm{K}_{2} \mathrm{~S}_{2} \mathrm{O}_{8}$ and $\mathrm{NaHCO}_{3}$ from biogenic uraninite when compared to that of chemogenic uraninite that was observed in this study. For example, for the reaction with $8.2 \mathrm{mg} \mathrm{L}^{-1} \mathrm{DO}$ and $100 \mathrm{mM}$ $\mathrm{NaHCO}_{3}$, the rate constant for biogenic uraninite oxidation was $6.2 \times 10^{-7} \mathrm{~mol} \cdot \mathrm{g} \mathrm{U}^{1-} \cdot \mathrm{s}^{-1}$ while that for chemogenic uraninite was $1.0 \times 10^{-9} \mathrm{~mol} \cdot \mathrm{g} \mathrm{U}^{1-} \cdot \mathrm{s}^{-1}$. Although the rate constants and associated rates from this study were obtained from batch experiments, the dissolution rate for chemogenic uraninite, now expressed per unit mass of $\mathrm{UO}_{2},\left(8.9 \times 10^{-10} \mathrm{~mol} \cdot \mathrm{g} \mathrm{UO}_{2}{ }^{-1}\right.$. $\left.\mathrm{s}^{-1}\right)$ is just over an order of magnitude lower than a rate reported in a previous study $\left(3.0 \times 10^{-8} \mathrm{~mol} \cdot \mathrm{g} \mathrm{UO}_{2}^{-1} \cdot \mathrm{s}^{-1}\right)$ performed using continuous flow tank reactors under oxidizing conditions. $^{20}$ This may be due to differences in the reactor types (batch vs continuous-flow) that affect the accumulation of $\mathrm{U}(\mathrm{VI})$ products in the system. The rate constant of dissolution for biogenic uraninite reported in this study $\left(5.5 \times 10^{-7} \mathrm{~mol} \cdot \mathrm{g}\right.$ $\mathrm{UO}_{2}{ }^{-1} \cdot \mathrm{s}^{-1}$ ), which is equivalent to the initial dissolution rate (eq 4), was also an order of magnitude higher than that obtained by Ulrich et al. ${ }^{20}$ under oxidizing conditions ( (5-7) $\left.\times 10^{-8} \mathrm{~mol} \cdot \mathrm{g} \mathrm{UO}_{2}^{-1} \cdot \mathrm{s}^{-1}\right)$. Another difference is that the biogenic uraninite used in this study was associated with biomass; the biogenic uraninite used by Ulrich et al. ${ }^{20}$ was treated with $1 \mathrm{M} \mathrm{NaOH}$ to isolate the material from biomass. The treatment with $\mathrm{NaOH}$ could have removed monomeric $\mathrm{U}(\mathrm{IV})$ as well as biomass from the biogenic uraninite sample used by Ulrich et al. ${ }^{20}$ a) $\quad 8.2 \mathrm{mg} \mathrm{L}^{-1} \mathrm{DO}$

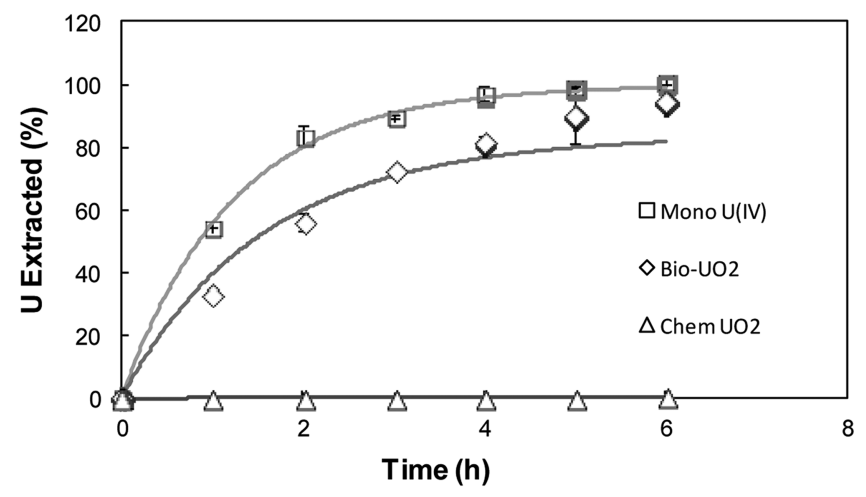

b)
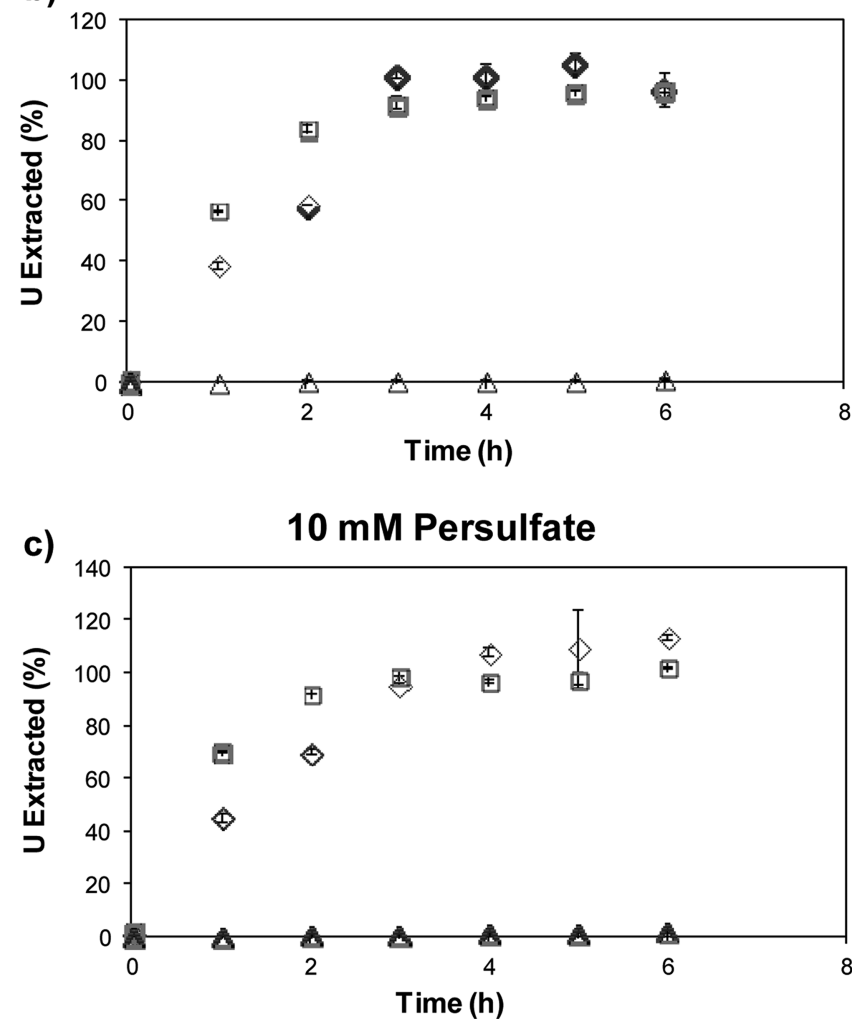

Figure 2. Oxidation of monomeric U(IV), biogenic uraninite not washed with $\mathrm{HCO}_{3}^{-}\left(\mathrm{Bio} \mathrm{UO}_{2}\right)$, and chemogenic uraninite (Chem $\mathrm{UO}_{2}$ ) with $100 \mathrm{mM} \mathrm{HCO}{ }^{-}$under the following conditions: (a) 8.2 $\mathrm{mg} \mathrm{L} \mathrm{L}^{-1}$ dissolved oxygen (DO), (b) $2 \mathrm{mM}$ potassium persulfate $\left(\mathrm{K}_{2} \mathrm{~S}_{2} \mathrm{O}_{8}\right)$; and (c) $10 \mathrm{mM} \mathrm{K} \mathrm{S}_{2} \mathrm{O}_{8}$. The error bars on most of the data points were smaller than the size of the points. In panel a, the data are shown together with simulations (lines) based on the oxidation rate interpretation using eq 1-5.

Monomeric U(IV) species bound to biomass were more susceptible than biogenic uraninite to oxidation by DO (Figure $2 a)$. Both monomeric $U(I V)$ and biogenic uraninite follow similar trends of $U$ released over time when reacted with $2 \mathrm{mM}$ and $10 \mathrm{mM} \mathrm{K}_{2} \mathrm{~S}_{2} \mathrm{O}_{8}$ and $100 \mathrm{mM} \mathrm{NaHCO}_{3}$ (b and $\mathrm{c}$ of Figure $2)$, confirming the susceptibility of these biogenic U(IV) species to oxidation with persulfate. Since DO is a milder oxidant than persulfate, the differences in $U$ released from biogenic uraninite and monomericU(IV) over time were more noticeable in the presence of DO. A concentration of $8.2 \mathrm{mg}$ $\mathrm{L}^{-1} \mathrm{DO}$ was sufficient to oxidize all of the biogenic uraninite and monomeric $\mathrm{U}(\mathrm{IV})$ after $6 \mathrm{~h}$ of reaction (Figure $2 \mathrm{a}$ ). In 
Table 2. U Extracted from Individual Forms and Different Mixtures of Chemogenic Uraninite, Biogenic Uraninite, and Monomeric U(IV) Samples Reacted with $\mathrm{HCO}_{3}{ }^{-}, \mathrm{K}_{2} \mathrm{~S}_{2} \mathrm{O}_{8}$, and DO and Analyzed with X-ray Absorption Spectroscopy

\begin{tabular}{|c|c|c|c|c|}
\hline sample name & sample description & reactants in d.i. $\mathrm{H}_{2} \mathrm{O}$ & $\begin{array}{l}\text { reaction } \\
\text { time }(\mathrm{h})\end{array}$ & $\begin{array}{l}\% \mathrm{U} \\
\text { extracted }\end{array}$ \\
\hline $\begin{array}{l}\text { Mono-Chem Mix } \\
\text { Anoxic }\end{array}$ & $50 \%$ monomeric $\mathrm{U}(\mathrm{IV})+50 \%$ chemogenic uraninite (anoxic control) & $100 \mathrm{mM} \mathrm{HCO}_{3}^{-}$ & 6 & 1 \\
\hline $\begin{array}{l}\text { Chem } \mathrm{UO}_{2}+ \\
\mathrm{K}_{2} \mathrm{~S}_{2} \mathrm{O}_{8}\end{array}$ & $100 \%$ chemogenic uraninite & $\begin{array}{l}100 \mathrm{mM} \mathrm{HCO}_{3}^{-}+50 \mathrm{mM} \\
\mathrm{K}_{2} \mathrm{~S}_{2} \mathrm{O}_{8}\end{array}$ & 6 & 30 \\
\hline $\begin{array}{l}\text { Mono } \mathrm{U}(\mathrm{IV})+ \\
\mathrm{K}_{2} \mathrm{~S}_{2} \mathrm{O}_{8}\end{array}$ & $90 \%$ monomeric $\mathrm{U}(\mathrm{IV})$ and $10 \%$ biogenic uraninite & $\begin{array}{l}100 \mathrm{mM} \mathrm{HCO}_{3}^{-}+50 \mathrm{mM} \\
\mathrm{K}_{2} \mathrm{~S}_{2} \mathrm{O}_{8}\end{array}$ & 6 & 100 \\
\hline $\begin{array}{l}\text { Mono-Chem Mix } \\
\text { Oxidized }\end{array}$ & $50 \%$ monomeric $\mathrm{U}(\mathrm{IV})+50 \%$ chemogenic uraninite & $\begin{array}{l}100 \mathrm{mM} \mathrm{HCO}_{3}^{-}+50 \mathrm{mM} \\
\mathrm{K}_{2} \mathrm{~S}_{2} \mathrm{O}_{8}\end{array}$ & 6 & 59 \\
\hline Bio $\mathrm{UO}_{2}+\mathrm{K}_{2} \mathrm{~S}_{2} \mathrm{O}_{8}$ & $\begin{array}{l}\text { biogenic uraninite not washed with } \mathrm{HCO}_{3}{ }^{-} \text {, [which contains } 65 \% \text { biogenic uraninite } \\
\text { and } \sim 35 \% \text { monomeric } \mathrm{U}(\mathrm{IV})]\end{array}$ & $\begin{array}{l}100 \mathrm{mM} \mathrm{HCO}_{3}^{-}+50 \mathrm{mM} \\
\mathrm{K}_{2} \mathrm{~S}_{2} \mathrm{O}_{8}\end{array}$ & 6 & 100 \\
\hline Bio $\mathrm{UO}_{2}+\mathrm{DO}$ & $\begin{array}{l}\text { biogenic uraninite not washed with } \mathrm{HCO}_{3}{ }^{-} \text {, [which contains } 65 \% \text { biogenic uraninite } \\
\text { and } \sim 35 \% \text { monomeric } \mathrm{U}(\mathrm{IV})]\end{array}$ & $\begin{array}{l}100 \mathrm{mM} \mathrm{HCO}_{3}^{-}+8.2 \\
\mathrm{mg} \mathrm{L}^{-1} \mathrm{DO}\end{array}$ & 2 & 92 \\
\hline $\begin{array}{l}\text { Washed } \mathrm{Bio} \mathrm{UO}_{2}+ \\
\text { DO }\end{array}$ & biogenic uraninite washed with $1 \mathrm{M} \mathrm{HCO}_{3}^{-}$[to remove monomeric U(IV)] & $\begin{array}{l}100 \mathrm{mM} \mathrm{HCO}_{3}^{-}+8.2 \\
\mathrm{mg} \mathrm{L}^{-1} \mathrm{DO}\end{array}$ & 2 & 52 \\
\hline
\end{tabular}
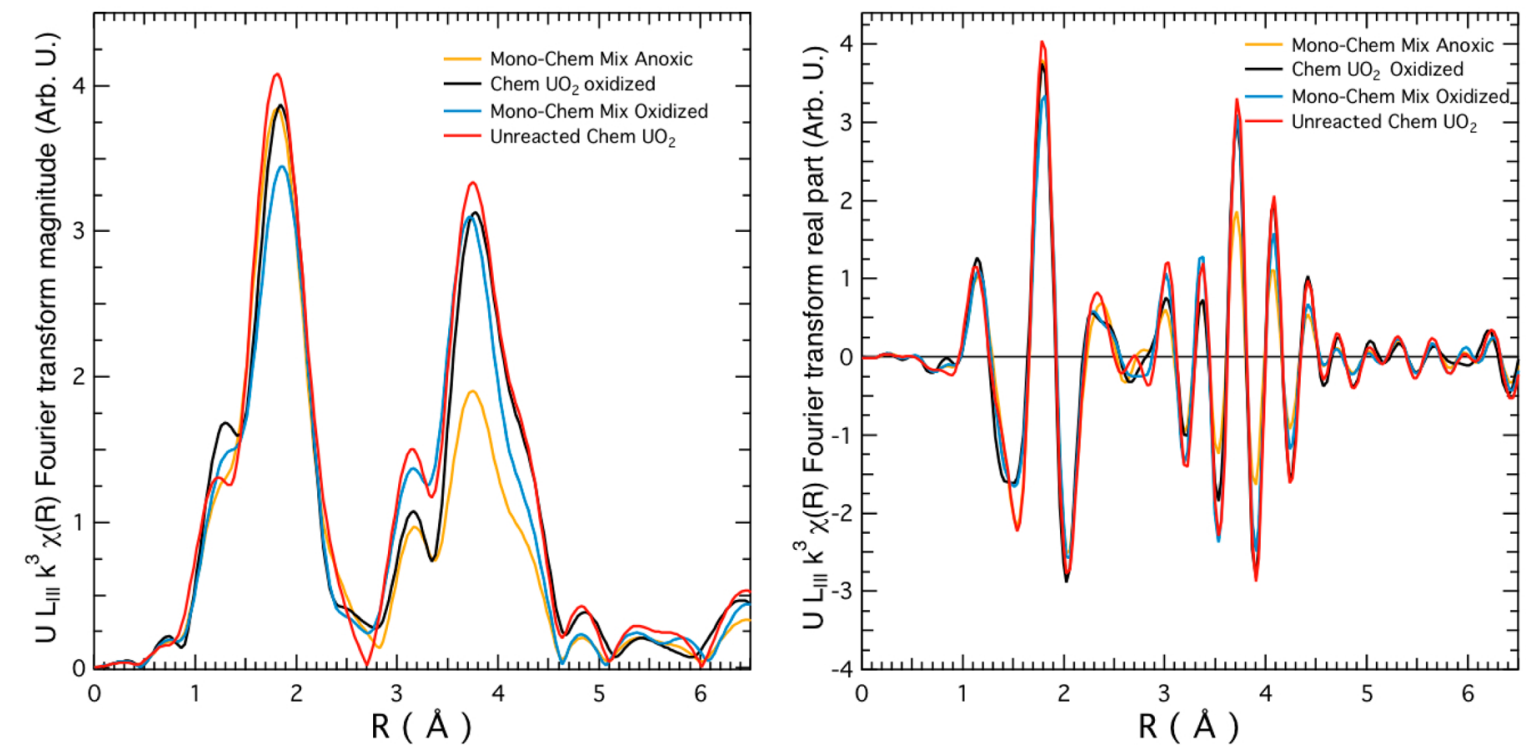

Figure 3. $\mathrm{U} \mathrm{L}_{\mathrm{III}}$-edge Fourier-transformed EXAFS spectra (Left: Magnitude, Right: Real-part) for a $50 \%$ chemogenic $\mathrm{UO}_{2}$ and $50 \%$ monomeric $\mathrm{U}(\mathrm{IV})$ mixture exposed to $100 \mathrm{mM} \mathrm{HCO}_{3}^{-}$both with an oxidant (Mono-Chem Mix Oxidized with $50 \mathrm{mM}$ persulfate) and without (Mono-Chemic

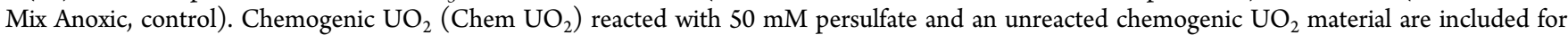
comparison.

terms of the oxidation rate constants, the value determined for monomeric U(IV) $\left(9.9 \times 10^{-7} \mathrm{~mol} \cdot \mathrm{g} \mathrm{U}^{1-} \cdot \mathrm{s}^{-1}\right)$ was only slightly higher than that determined for biogenic uraninite $(6.2$ $\left.\times 10^{-7} \mathrm{~mol} \cdot \mathrm{g} \mathrm{U}^{1-} \cdot \mathrm{s}^{-1}\right)$.

Oxidation Experiments with Mixtures of U(IV)Containing Materials. We performed additional experiments to evaluate the selectivity of persulfate and oxygen to extract specific U(IV) species. X-ray absorption spectroscopy (XAS) analyses were conducted to further investigate the effect of oxidation reactions on mixtures of U(IV)-containing materials. The amounts of $U$ extracted from individual forms and mixtures of U(IV) samples exposed under specific oxidizing conditions are presented in Table 2 . Only $1 \%$ of the total $U$ was solubilized from a mixture consisting of $50 \%$ monomeric U(IV) and $50 \%$ chemogenic uraninite (Mono-Chem Mix Anoxic, control) when reacted under anoxic conditions with $100 \mathrm{mM}$ $\mathrm{NaHCO}_{3}$ at $\mathrm{pH} 8.3$ for $6 \mathrm{~h}$; the small fraction of $\mathrm{U}$ extracted from this mixture was likely surface-associated $\mathrm{U}(\mathrm{VI})$. This conjecture was supported by the XANES spectra (Figure S3 in the Supporting Information) which show that the peak for this anoxic sample is slightly wider than that of a $\mathrm{UO}_{2.00}$ reference material due to a small fraction of $\mathrm{U}(\mathrm{VI})$ present in the mixture of $50 \%$ monomeric $\mathrm{U}(\mathrm{IV})$ and $50 \%$ chemogenic uraninite. There are no detectable differences between the XANES spectra for the anoxic sample and the others exposed to oxidizing conditions. It is likely that the $100 \mathrm{mM} \mathrm{NaHCO}$ used for these experiments solubilized U(VI) from the oxidized samples so that essentially no U(VI) remained with the solid phase to be detected in the XANES spectra. The fraction of $U$ extracted from all other samples exposed to oxidizing conditions was equal to or greater than $30 \%$. Solids recovered from these experiments were further characterized with EXAFS to investigate the oxidation of the specific U(IV) species included in each of the mixtures tested.

The Fourier transforms of the EXAFS spectra (Figure 3) suggest that monomeric U(IV) was more readily extracted from the mixed samples due to its oxidation by persulfate. This can be confirmed by the increase in the amplitude of the peak near $3.85 \AA$ (associated with the U-U shell observed in uraninite), indicating that the relative fraction of uraninite in this sample 
had increased after persulfate oxidation of the sample. The amplitude of the U-U shell of the sample mixtures oxidized with persulfate (Mono-Chem Mix Oxidized) is similar to that of the unreacted chemogenic uraninite sample (anoxic control). Note that the Fourier transform of the spectrum of the sample with a mixture of $50 \%$ monomeric U(IV) and 50\% chemogenic uraninite under anoxic conditions (Mono-Chem Mix Anoxic) has the lowest amplitude of the U-U shell; the low amplitude of the U-U shell in this mixture is due to the contribution of noncrystalline monomeric U(IV) as observed by Alessi et al. ${ }^{12}$ Monomeric U(IV) does not have a U-U shell and, thus, its presence interferes with the signal of uraninite in the mixed sample. When monomeric U(IV) is oxidized this interference effect disappears, causing an increase in the amplitude of the $\mathrm{U}-\mathrm{U}$ shell due to the contribution of the remaining chemogenic uraninite.

Although the oxidative dissolution of chemogenic uraninite by persulfate is thermodynamically favorable, the prevalence of the bulk chemogenic uraninite material can be observed in the Fourier transform of the EXAFS spectra even after $6 \mathrm{~h}$ of reaction time with $50 \mathrm{mM} \mathrm{K}_{2} \mathrm{~S}_{2} \mathrm{O}_{8}$ and $100 \mathrm{mM} \mathrm{NaHCO}_{3}$. This is consistent with the results shown in Table 2 that indicate incomplete $(30 \% \mathrm{U})$ extraction from the chemogenic uraninite sample after $6 \mathrm{~h}$ of reaction with $50 \mathrm{mM} \mathrm{K} \mathrm{S}_{2} \mathrm{O}_{8}$ and $100 \mathrm{mM}$ $\mathrm{NaHCO}_{3}$. Thus, more than $6 \mathrm{~h}$ would be required for complete oxidation of chemogenic uraninite to occur.

Environmental Implications. Recent investigations have reported that a mixture of biogenic uraninite and monomeric $\mathrm{U}(\mathrm{IV})$ is present in bioreduced sediments. ${ }^{2,12,14}$ Thus, characterizing the stability of these $\mathrm{U}(\mathrm{IV})$ products is necessary to understand the fate and transport of uranium in subsurface environments. The results of this study indicate that monomeric $\mathrm{U}(\mathrm{IV})$ is slightly more susceptible to oxidation than biogenic uraninite in the presence of dissolved oxygen. These results could at least partially explain the often rapid reoxidation of uranium reported in other bioreduction experiments. ${ }^{23,24}$ Monomeric U(IV) bound to biomass, biogenic vivianite and magnetite, and a field sediment from Rifle, $\mathrm{CO}$, are more labile than uraninite when exposed to bicarbonate. ${ }^{12}$ More ligand-extractable $U$ was released from monomeric $\mathrm{U}(\mathrm{IV})$ as compared to biogenic and chemogenic uraninite in this study. Chemogenic uraninite was more stable than monomeric U(IV) and biogenic uraninite when reacted with the chemical extractants used in this study.

It should be noted that the present study focused on understanding the relative rates of $U$ release from biogenic and chemogenic uraninite and monomeric $U(I V)$ when reacted under controlled experimental conditions. Future research can couple this information on the rates of chemical processes with advective and diffusive transport processes through the use of reactive transport models. Our results suggest that exposure to oxidants (e.g., dissolved oxygen) is more important than the actual form of biogenic $\mathrm{U}(\mathrm{IV})$, given the major differences in $\mathrm{U}$ release in the presence and absence of oxidants and the minor differences observed in the oxidation rate constants of biogenic uraninite and monomeric U(IV). Consequently, the transport processes that control the exposure of biogenic U(IV) species to dissolved oxygen will be critical to assessing the long-term fate of uranium in actual subsurface environments. The importance of diffusion-limited microsites for sequestering $\mathrm{U}$ in natural systems has been reported in other studies. ${ }^{34-36}$ Another aspect to consider is that the specific surface area of biogenic uraninite will vary depending on the particle size, and the accessibility of monomeric U(IV) to oxygen can be affected by the nature of the biomass with which it is associated. Thus, reactive transport models applied to the context of bioremediated and natural subsurface environments should take into account diffusive transport processes and the physical characteristics of the U(IV) species when incorporating the reaction rate constants presented in this study.

Bioremediation strategies should aim to minimize the contribution of monomeric U(IV) to the total U(IV) produced during microbial in situ reduction of $\mathrm{U}(\mathrm{VI})$, and methods that result in the most crystalline and lowest surface area forms of uraninite will be most resistant to oxidative remobilization of the uranium. Understanding the factors that control the stability of U(IV) species in subsurface environments is of fundamental importance toward the long-term optimization of in situ bioremediation strategies.

\section{ASSOCIATED CONTENT}

\section{S Supporting Information}

Two additional tables ( $S 1$ and S2), six additional figures (S1S6), and discussion of the oxidation rate analysis. This material is available free of charge via the Internet at http://pubs.acs.org.

\section{AUTHOR INFORMATION}

\section{Corresponding Author}

*E-mail: cerratoj@wustl.edu. Telephone: (001) (314) 9353457. Fax: (001) (314) 935-5464.

\section{Present Address}

†Department of Earth and Earth System Science, Stanford University, Stanford, California 94305, United States.

\section{Notes}

The contents of this publication are solely the responsibility of the authors and do not necessarily represent the official views of NIGMS, NCRR or NIH.

The authors declare no competing financial interest.

\section{ACKNOWLEDGMENTS}

Funding for this research was provided by the U.S. Department of Energy, Office of Biological and Environmental Research, Climate and Environmental Sciences Division, as part of the SLAC Science Focus Area Research Program (FWP \#10094). Portions of this research were carried out at the Stanford Synchrotron Radiation Lightsource, a Directorate of SLAC National Accelerator Laboratory and an Office of Science User Facility operated for the U.S. Department of Energy Office of Science by Stanford University. The SSRL Structural Molecular Biology Program is supported by the DOE Office of Biological and Environmental Research and by the National Institutes of Health, National Institute of General Medical Sciences (including P41GM103393). We appreciate the comments received from four anonymous reviewers which were helpful to improve this document.

\section{REFERENCES}

(1) Manual of Acid in Situ Leach Uranium Mining Technology; International Atomic Energy Agency: Vienna, 2001; p 294.

(2) Bargar, J. R.; Williams, K. H.; Campbell, K. M.; Long, P. E.; Stubbs, J. E.; Suvorova, E. I.; Lezama-Pacheco, J. S.; Alessi, D. S.; Stylo, M.; Webb, S. M.; Davis, J. A.; Giammar, D. E.; Blue, L. Y.; BernierLatmani, R. Uranium redox transition pathways in acetate-amended sediments. Proc. Natl. Acad. Sci. U.S.A. 2013, 110 (12), 4506-4511. 
(3) Lovley, D. R.; Phillips, E. J. P. Bioremediation of uranium contamination with enzymatic uranium reduction. Environ. Sci. Technol. 1992, 26 (11), 2228-2234.

(4) Lovley, D. R.; Phillips, E. J. P. Reduction of uranium by Desulfovibrio desulfuricans. Appl. Environ. Microbiol. 1992, 58 (3), 850856.

(5) Anderson, R. T.; Vrionis, H. A.; Ortiz-Bernad, I.; Resch, C. T.; Long, P. E.; Dayvault, R.; Karp, K.; Marutzky, S.; Metzler, D. R.; Peacock, A.; White, D. C.; Lowe, M.; Lovley, D. R. Stimulating the in situ activity of Geobacter species to remove uranium from the groundwater of a uranium-contaminated aquifer. Appl. Environ. Microbiol. 2003, 69 (10), 5884-5891.

(6) Yabusaki, S. B.; Fang, Y.; Long, P. E.; Resch, C. T.; Peacock, A. D.; Komlos, J.; Jaffe, P. R.; Morrison, S. J.; Dayvault, R. D.; White, D. C.; Anderson, R. T. Uranium removal from groundwater via in situ biostimulation: Field-scale modeling of transport and biological processes. J. Contam. Hydrol. 2007, 93 (1-4), 216-235.

(7) Williams, K. H.; Long, P. E.; Davis, J. A.; Wilkins, M. J.; N'Guessan, A. L.; Steefel, C. I.; Yang, L.; Newcomer, D.; Spane, F. A.; Kerkhof, L. J.; McGuinness, L.; Dayvault, R.; Lovley, D. R. Acetate availability and its influence on sustainable bioremediation of uraniumcontaminated groundwater. Geomicrobiol. J. 2011, 28 (5-6), 519-539.

(8) Schofield, E. J.; Veeramani, H.; Sharp, J. O.; Suvorova, E.; Bernier-Latmani, R.; Mehta, A.; Stahlman, J.; Webb, S. M.; Clark, D. L.; Conradson, S. D.; Ilton, E. S.; Bargar, J. R. Structure of biogenic uraninite produced by Shewanella oneidensis strain MR-1. Environ. Sci. Technol. 2008, 42 (21), 7898-7904.

(9) Fletcher, K. E.; Boyanov, M. I.; Thomas, S. H.; Wu, Q. Z.; Kemner, K. M.; Loffler, F. E. U(VI) reduction to mononuclear U(IV) by Desulfitobacterium species. Environ. Sci. Technol. 2010, 44 (12), 4705-4709.

(10) Bernier-Latmani, R.; Veeramani, H.; Vecchia, E. D.; LezamaPacheco, J. S.; Suvorova, E. I.; Sharp, J. O.; Wigginton, N. S.; Bargar, J. R. Non-uraninite products of microbial U(VI) reduction. Environ. Sci. Technol. 2010, 44 (24), 9456-9462.

(11) Boyanov, M. I.; Fletcher, K. E.; Kwon, M. J.; Rui, X.; O'Loughlin, E. J.; Loffler, F. E.; Kemner, K. M. Solution and microbial controls on the formation of reduced U(IV) species. Environ. Sci. Technol. 2011, 45 (19), 8336-8344.

(12) Alessi, D. S.; Uster, B.; Veeramani, H.; Suvorova, E. I.; LezamaPacheco, J. S.; Stubbs, J. E.; Bargar, J. R.; Bernier-Latmani, R. Quantitative separation of monomeric U(IV) from $\mathrm{UO}_{2}$ in products of U(VI) reduction. Environ. Sci. Technol. 2012, 46 (11), 6150-6157.

(13) Sivaswamy, V.; Boyanov, M. I.; Peyton, B. M.; Viamajala, S.; Gerlach, R.; Apel, W. A.; Sani, R. K.; Dohnalkova, A.; Kemner, K. M.; Borch, T. Multiple mechanisms of uranium immobilization by Cellulomonas sp strain ES6. Biotechnol. Bioeng. 2011, 108 (2), 264276.

(14) Sharp, J. O.; Lezama-Pacheco, J. S.; Schofield, E. J.; Junier, P.; Ulrich, K. U.; Chinni, S.; Veeramani, H.; Margot-Roquier, C.; Webb, S. M.; Tebo, B. M.; Giammar, D. E.; Bargar, J. R.; Bernier-Latmani, R. Uranium speciation and stability after reductive immobilization in aquifer sediments. Geochim. Cosmochim. Acta 2011, 75 (21), 64976510.

(15) Veeramani, H.; Alessi, D. S.; Suvorova, E. I.; Lezama-Pacheco, J. S.; Stubbs, J. E.; Sharp, J. O.; Dippon, U.; Kappler, A.; Bargar, J. R.; Bernier-Latmani, R. Products of abiotic U(VI) reduction by biogenic magnetite and vivianite. Geochim. Cosmochim. Acta 2011, 75 (9), $2512-2528$.

(16) Latta, D. E.; Boyanov, M. I.; Kemner, K. M.; O’Loughlin, E. J.; Scherer, M. M. Abiotic reduction of uranium by Fe(II) in soil. Appl. Geochem. 2012, 27 (8), 1512-1524.

(17) Casas, I.; Gimenez, J.; Marti, V.; Torrero, M. E.; Depablo, J. Kinetic studies of unirradiated $\mathrm{UO}_{2}$ dissolution under oxidizing conditions in batch and flow experiments. Radiochim. Acta 1994, 66/ 67 (7), 23-27.

(18) Pierce, E. M.; Icenhower, J. P.; Serne, R. J.; Catalano, J. G. Experimental determination of $\mathrm{UO}_{2}(\mathrm{cr})$ dissolution kinetics: Effects of solution saturation state and $\mathrm{pH}$. J. Nucl. Mater. 2005, 345 (2-3), 206-218.

(19) Ulrich, K. U.; Singh, A.; Schofield, E. J.; Bargar, J. R.; Veeramani, H.; Sharp, J. O.; Bernier-Latmani, R.; Giammar, D. E. Dissolution of biogenic and synthetic $\mathrm{UO}_{2}$ under varied reducing conditions. Environ. Sci. Technol. 2008, 42 (15), 5600-5606.

(20) Ulrich, K. U.; Ilton, E. S.; Veeramani, H.; Sharp, J. O.; BernierLatmani, R.; Schofield, E. J.; Bargar, J. R.; Giammar, D. E. Comparative dissolution kinetics of biogenic and chemogenic uraninite under oxidizing conditions in the presence of carbonate. Geochim. Cosmochim. Acta 2009, 73 (20), 6065-6083.

(21) Shoesmith, D. W. Fuel corrosion processes under waste disposal conditions. J. Nucl. Mater. 2000, 282 (1), 1-31.

(22) Cerrato, J. M.; Barrows, C. J.; Blue, L. Y.; Lezama-Pacheco, J. S.; Bargar, J. R.; Giammar, D. E. Effect of $\mathrm{Ca}^{2+}$ and $\mathrm{Zn}^{2+}$ on $\mathrm{UO}_{2}$ dissolution rates. Environ. Sci. Technol. 2012, 46 (5), 2731-2737.

(23) Moon, H. S.; Komlos, J.; Jaffe, P. R. Uranium reoxidation in previously bioreduced sediment by dissolved oxygen and nitrate. Environ. Sci. Technol. 2007, 41 (13), 4587-4592.

(24) Komlos, J.; Mishra, B.; Lanzirotti, A.; Myneni, S. C. B.; Jaffe, P. $\mathrm{R}$. Real-time speciation of uranium during active bioremediation and U(IV) reoxidation. J. Environ. Eng. 2008, 134 (2), 78-86.

(25) Luan, F.; Burgos, W. D. Sequential extraction method for determination of $\mathrm{Fe}(\mathrm{II} / \mathrm{III})$ and $\mathrm{U}(\mathrm{IV} / \mathrm{VI})$ in suspensions of ironbearing phyllosilicates and uranium. Environ. Sci. Technol. 2012, 46 (21), 11995-12002.

(26) Veeramani, H.; Schofield, E. J.; Sharp, J. O.; Suvorova, E. I.; Ulrich, K.-U.; Mehta, A.; Giammar, D. E.; Bargar, J. R.; BernierLatmani, R. Effect of $\mathrm{Mn}$ (II) on the structure and reactivity of biogenic uraninite. Environ. Sci. Technol. 2009, 43 (17), 6541-6547.

(27) Sawyer, C.; McCarty, P.; Parkin, G. Chemistry for Environmental Engineering and Science; McGraw-Hill: New York, 2002.

(28) Kelly, S. D.; Hesterberg, D.; Ravel, B. Analysis of soils and minerals using X-ray absorption spectroscopy. In Methods of Soil Analysis, Part 5: Mineralogical Methods; Ulery, A. L., Drees, L. R., Eds.; Soil Science Society of America: Madison, WI, 2008; pp 367-463.

(29) Hennig, C. Evidence for double-electron excitations in the $\mathrm{L}_{3}$ edge X-ray absorption spectra of actinides. Phys. Rev. B 2007, 75 (3), 035120.

(30) Schecher, W. D.; McAvoy, D. C. MINEQL+: A chemical equilibrium modeling system, version 4.6; Environmental Research Software: Hallowell, ME, 2007.

(31) Grenthe, I.; Fuger, J.; Konings, R. J. M.; Lemire, R. J.; Mueller, A. B.; Nguyen-Trung, C.; Wanner, H. Chemical Thermodynamics of Uranium. Elsevier: Amsterdam, 1992.

(32) Guillaumont, R.; Fanghänel, T.; Fuger, J.; Grenthe, I.; Neck, V.; Palmer, D. A.; Rand, M. H. Update on the Chemical Thermodynamics of Uranium, Neptunium, Plutonium, Americium and Technetium. Elsevier: Amsterdam, 2003.

(33) Sharp, J. O.; Schofield, E. J.; Veeramani, H.; Suvorova, E. I.; Kennedy, D. W.; Marshall, M. J.; Mehta, A.; Bargar, J. R.; BernierLatmani, R. Structural Similarities between Biogenic Uraninites Produced by Phylogenetically and Metabolically Diverse Bacteria. Environ. Sci. Technol. 2009, 43 (21), 8295-8301.

(34) Liu, C. X.; Zachara, J. M.; Qafoku, O.; McKinley, J. P.; Heald, S. M.; Wang, Z. M. Dissolution of uranyl microprecipitates in subsurface sediments at Hanford site, USA. Geochim. Cosmochim. Acta 2004, 68 (22), 4519-4537.

(35) Tokunaga, T. K.; Wan, J. M.; Pena, J.; Brodie, E. L.; Firestone, M. K.; Hazen, T. C.; Sutton, S. R.; Lanzirotti, A.; Newville, M. Uranium reduction in sediments under diffusion-limited transport of organic carbon. Environ. Sci. Technol. 2005, 39 (18), 7077-7083.

(36) Giammar, D. E.; Cerrato, J. M.; Mehta, V.; Wang, Z.; Wang, Y.; Pepping, T. J.; Ulrich, K.-U.; Lezama-Pacheco, J. S.; Bargar, J. R. Effect of diffusive transport limitations on $\mathrm{UO}_{2}$ dissolution. Water Res. 2012, 46 (18), 6023-6032. 